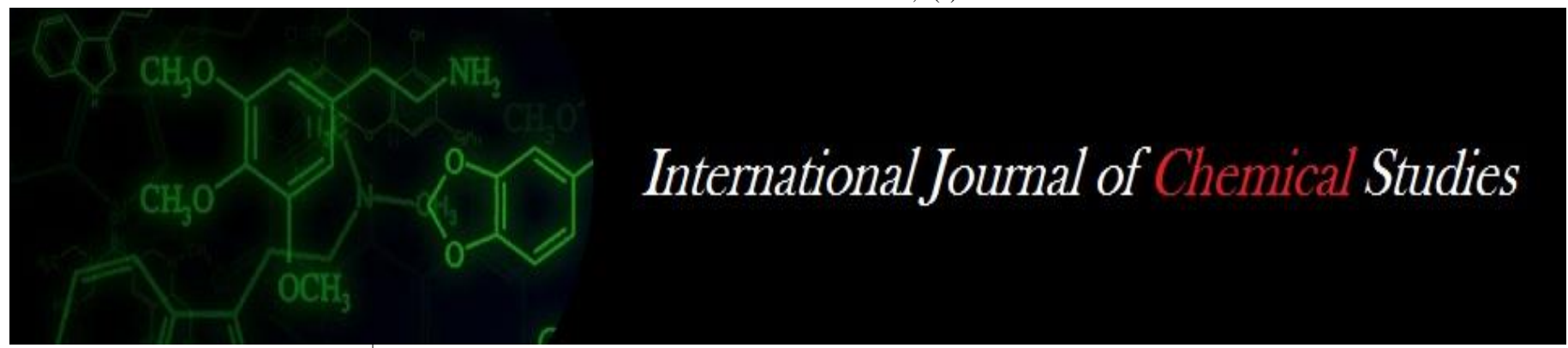

P-ISSN: 2349-8528

E-ISSN: 2321-4902

www.chemijournal.com

IJCS 2020; 8(3): 2693-2696

(C) 2020 IJCS

Received: 11-03-2020

Accepted: 13-04-2020

\section{RS Bhadane}

Oilseeds Research Station,

Mahatma Phule Agricultural

University, Jalgaon

Maharashtra, India

KR Prajapat

Vanbandhu Krishi Polytechnic

School, S. K. Nagar Agriculture

University, Amirgadh Gujarat,

India

\section{KC Ombase}

Zonal Agricultural Research

Station, Mahatma Phule

Agricultural University,

Solapur, Maharashtra, India

\section{DB Patel}

Ex. Professor \& Head,

Department of Plant Physiology,

B. A. College of Agriculture,

Anand Agricultural University,

Anand, Gujarat, India
Corresponding Author: RS Bhadane

Oilseeds Research Station,

Mahatma Phule Agricultural

University, Jalgaon,

Maharashtra, India

\section{Seed hardening, foliar spraying and their combined effect on biochemical parameters in green gram (Vigna radiata L. Wilckzek) cv. GAM- 5}

\author{
RS Bhadane, KR Prajapati, KC Ombase and DB Patel
}

DOI: $\underline{\text { htps://doi.org/10.22271/chemi.2020.v8.i3am.9619 }}$

\begin{abstract}
A field experiment was conducted to evaluate seed hardening, foliar spraying and their combined effect on biochemical characters in green gram. The mung bean var. GAM-5 was imposed with seed hardening treatments and also for foliar spray using $\mathrm{CaCl}_{2} 2 \% \& 1 \%$, CCC $500 \mathrm{mg} / \mathrm{L}$, CCC $1000 \mathrm{mg} / \mathrm{L}$, NAA 25 $\mathrm{mg} / \mathrm{L}$, NAA $50 \mathrm{mg} / \mathrm{L}$. The trial was laid out in RBD with three replications and sixteen treatment combinations including five seed hardening treatments, five foliar spraying treatments, five seed hardening treatments with foliar spraying and one absolute control treatment during summer season of 16 and 2017. These treatments were evaluated for their biochemical parameters at field conditions. It was found that continuous increase in chlorophyll content was noted up to 60 DAS, thereafter it decreased during both the seasons at senescence stage. It is clear that there was increase in nitrogen content and seed protein content in all the treatments like seed hardening, foliar spraying singly or their combined effect as compared to control. Therefore, the treatment $\mathrm{T}_{11}$ was more efficient in chlorophyll content in leaves, nitrogen content and protein content in seed as compared to other treatments and control.
\end{abstract}

Keywords: Biochemical parameters, $\mathrm{CaCl}_{2}$, Chlorophyll, Cycocel, Foliar spray, Mung bean, NAA, Nitrogen, Protein, Seed hardening

\section{Introduction}

Mung bean (Vigna radiata L.) belongs to the family Leguminoceae (Fabaceae) and had originated from India and Central Asia. Mung bean is one of the important pulse crops and rank third in area and production after pigeonpea and chickpea. Mung bean is grown in almost all parts of the country over a wide range of agro-climatic conditions. India is the largest producer of mung bean in the world. The productivity of mung bean is low. The use of plant growth regulators are known to improve the physiological efficiency including photosynthetic ability of plants and offer a significant role in realizing higher crop yields. The PGRs are also known to enhance the source-sink relationship and stimulate the translocation of photoassimilates, thereby increasing the productivity (Taiz and Zeiger, 2003) ${ }^{[20]}$. Mung bean is a very good catch crop in summer and can be grown very well in this season. It is a short duration, low input requiring crop that matures in 65 to 80 days, photo and thermo-insensitive in nature.

Efforts made to maximize yield, is largely hampered by adverse effect of a biotic stress such as salinity and drought. These effects cause a huge loss due to low yield and failure of the crop to establish in some cases. Pre-sowing hardening seed treatment is an easy, low cost and low risk technique and also an alternative approach recently used to overcome the effect of abiotic stresses in agricultural production. It is found to be efficient in improving seed emergence and growth of crops (Sankar Ganesh et al., 2013; Patel et al., 2017) ${ }^{[16,14]}$. It was reported clearly that the hardening treatment enhance seeds vigour by protecting structure of the plasma membrane against injury during stress (Bewley and Black, 1982; JunMin et al., 2000) ${ }^{[3,9]}$. Considering the constraints in the production potential of mung bean it is worthwhile to study the influence of different seed hardening and foliar spraying treatments on the production potential of mung bean. It is also of utmost importance to understand the physiological basis of dry matter accumulation, its partitioning in various plant parts and thereby yield variation due 
to seed hardening and foliar spraying of various growth regulators and chemicals. The pre-requisite for higher yield is related with the ability of genotype to produce high amount of total dry matter.

Hence, the present study was undertaken for studying the effect on biochemical parameters by the use of plant growth regulators and agro chemical (Cycocel, NAA and $\mathrm{CaCl}_{2}$ ) under field conditions in two summer seasons.

\section{Materials \& Methods}

The present work was carried out at Agronomy farm, Anand Agricultural University, Anand to study the effect of seed hardening, foliar spraying and their combined effect on biochemical parameters in green gram (Vigna radiata L.) during summer season of 2016 and 2017. The trial was laid out in RBD with three replications and sixteen treatment combinations including five seed hardening treatments, five foliar spraying treatments, five seed hardening treatments with foliar spraying and one absolute control treatment. Seeds of mung bean var. GAM- 5 were imposed with the following seed treatments.

The different solutions with different concentrations viz., $\mathrm{CaCl}_{2} 2 \%$, Cycocel $500 \mathrm{mg} \mathrm{l}^{-1} \& 1000 \mathrm{mg} \mathrm{l}^{-1}$ and NAA $25 \mathrm{mg}$ $1^{-1} \& 50 \mathrm{mg} \mathrm{l}^{-1}$ were used in this experiment for seed hardening. For hardening, seeds were soaked in above prepared various solutions of double the volume of seed for three hours. This will ensure that seeds remained immersed in the solution, so as to avoid precocious germination during the treatment period. The seeds were then removed from respective solutions and kept overnight in shade for drying to attained the seeds to its original moisture level. The seeds were ready for sowing in field on next day.

The different solutions of $\mathrm{CaCl}_{2} 1 \%$, Cycocel $500 \mathrm{mg} \mathrm{l}^{-1} \&$ $1000 \mathrm{mg} \mathrm{l}^{-1}$ and NAA $25 \mathrm{mg} \mathrm{l}^{-1} \& 50 \mathrm{mg} \mathrm{l}^{-1}$ were used in this experiment for foliar spraying. The spraying was carried out as per treatments during the morning time or before noon at 30 days after sowing (DAS) in respective gross plot of each replication using knapsack sprayer.

\section{Estimation of Total Chlorophyll Content of Leaves}

Total chlorophyll content was obtained by the SPAD (soil plant analytical development) meter in which randomly three leaves were selected from lower, middle and upper leaves at different intervals at 30, 45, 60 DAS and at harvest. Before the measurement, instrument is calibrated - transmission is measured with no leaf inside. Thus, when a leaf is clamped by the meter, a certain portion of red light is absorbed and the meter can calculate a relative value (in SPAD), showing how green the leaf is. Basically, SPAD value correlates with actual chlorophyll content in the leaf, but measurements have to be taken at many points of the same leaf to be representative and calibration is to be performed for every plant species or cultivar to know the exact relationship between SPAD values and chlorophyll contents per unit area.

\section{Total Nitrogen (\%)}

Protein content in seeds was determined by Micro-Kjeldhal method (Miller and Houghton, 1945 and AOAC, 1990) ${ }^{[13,1]}$. The method consists of heating a substance with sulphuric acid, which decomposes the organic substance by oxidation to liberate the reduced nitrogen as ammonium sulphate. In this step potassium sulphate is added to increase the boiling point of the medium (from $337{ }^{\circ} \mathrm{C}$ to $373{ }^{\circ} \mathrm{C}$ ). Chemical decomposition of the sample is complete when the initially very dark-coloured medium has become clear and colourless. The solution is then distilled with a small quantity of sodium hydroxide, which converts the ammonium salt to ammonia. The amount of ammonia present, and thus the amount of nitrogen present in the sample, is determined by back titration. The end of the condenser is dipped into a solution of boric acid. The ammonia reacts with the acid and the remainder of the acid is then titrated with a sodium carbonate solution by way of a methyl orange $\mathrm{pH}$ indicator.

\section{Seed Protein Content (\%)}

The protein content was determined by Micro-Kjeldhal method (AOAC, 1990). A food is digested with a strong acid so that it releases nitrogen which can be determined by a suitable titration technique. The amount of protein present is then calculated from the nitrogen concentration of the food. It is usually considered to be the standard method of determining protein concentration. Because the Kjeldahl method does not measure the protein content directly. A conversion factor $(F)$ is needed to convert the measured nitrogen concentration to a protein concentration. A conversion factor of 6.25 (equivalent to $0.16 \mathrm{~g}$ nitrogen per gram of protein) is used for many applications, however, this is only an average value, and each protein has a different conversion factor depending on its amino-acid composition.

\section{Protein $(\%)=\mathrm{N}(\%)$ X 6.25}

The data were statistically analyzed using ANOVA.

\section{Results \& Discussion \\ Chlorophyll content of leaves-SPAD values at 30, 45, 60 DAS and at harvest}

In the present investigation, the results pertaining to the chlorophyll content of leaves (SPAD values) presented in Table 1 indicated non significant differences during both the years but it was significant in pooled. The pre-sowing seed hardening treatment with $2 \% \mathrm{CaCl}_{2}\left(\mathrm{~T}_{11} \& \mathrm{~T}_{1}\right)$ recorded significantly highest (31.77 and 31.68) chlorophyll content of leaves while untreated absolute control $\left(\mathrm{T}_{16}\right)$ recorded significantly the lowest (26.84) at 30 DAS during both years pooled analysis. Similarly, the treatment $\mathrm{T}_{11}$ recorded significantly highest chlorophyll content of leaves (SPAD values) (49.31) at 45 DAS growth stage, (53.11) at 60 DAS and (14.06) at harvest over untreated control treatment in pooled analysis.

From the data it is clear that continuous increase in chlorophyll content was noted up to 60 DAS, thereafter it decreased during both the seasons at senescence stage. The agrochemicals and growth substances such as $\mathrm{CaCl}_{2}$, Cycocel and NAA had a positive effect on cell division and cell elongation leading to enhanced leaf expansion, leaf area and thereby chlorophyll content also. The increase in chlorophyll content due to growth regulators and agrochemical may be attributed to decreased chlorophyll degradation and increased chlorophyll synthesis. These results are in accordance with Jayakumar and Thangaraj (1998) ${ }^{[8]}$, Shinde and Jadhav (1995) ${ }^{[17]}$, Dashora and Jain (1994) ${ }^{[6]}$, Pothalkar (2007) ${ }^{[15]}$ and Kinjal (2017) ${ }^{[10]}$ in groundnut, cowpea, soybean, pigeon pea and blackgram respectively. In the present investigation, the chlorophyll content showed a positive correlation with grain yield indicating its importance in yield determination. 
Table 1: Seed hardening, foliar spraying and their combined effect on Chlorophyll content at 30, 45, 60 DAS and at harvest (g/plant)

\begin{tabular}{|c|c|c|c|c|c|c|c|c|c|c|c|c|c|}
\hline \multirow{3}{*}{ Treat. No. } & \multirow{3}{*}{ Treatment Details } & \multicolumn{12}{|c|}{ Chlorophyll content of leaves ( SPAD values) } \\
\hline & & \multicolumn{3}{|c|}{ 30 DAS } & \multicolumn{3}{|c|}{ 45 DAS } & \multicolumn{3}{|c|}{\begin{tabular}{|c|}
60 DAS \\
\end{tabular}} & \multicolumn{3}{|c|}{ AT harvest } \\
\hline & & 2016 & 2017 & Pooled & 2016 & 2017 & Pooled & 2016 & 2017 & Pooled & 2016 & 2017 & Pooled \\
\hline $\mathrm{T}_{1}$ & $\mathrm{CaCl}_{2} 2 \% \mathrm{SH}$ & 30.62 & 32.75 & 31.68 & 43.67 & 47.12 & 45.39 & 47.80 & 50.07 & 48.93 & 10.35 & 511.87 & 11.11 \\
\hline $\mathrm{T}_{2}$ & CCC $500 \mathrm{mg} / \mathrm{L} \mathrm{SH}$ & 29.52 & 31.32 & 30.42 & 43.17 & 46.45 & 44.81 & 47.23 & 49.08 & 48.16 & 9.80 & 10.93 & 10.37 \\
\hline $\mathrm{T}_{3}$ & CCC $1000 \mathrm{mg} / \mathrm{L} \mathrm{SH}$ & 30.25 & 32.37 & 31.31 & 43.52 & 46.87 & 45.19 & 47.62 & 49.80 & 48.71 & 10.13 & \begin{tabular}{|l|l|} 
& 11.47 \\
\end{tabular} & 10.80 \\
\hline $\mathrm{T}_{4}$ & NAA 25 mg/L SH & 29.05 & 30.55 & 29.80 & 42.72 & 45.92 & 44.32 & 46.75 & 48.47 & 47.61 & 9.63 & 10.73 & 10.18 \\
\hline $\mathrm{T}_{5}$ & NAA $50 \mathrm{mg} / \mathrm{L} \mathrm{SH}$ & 29.78 & 31.52 & 30.65 & 43.28 & 46.62 & 44.95 & 47.35 & 49.35 & 48.35 & 10.00 & 11.30 & 10.65 \\
\hline $\mathrm{T}_{6}$ & $\mathrm{CaCl}_{2} 1 \%$ spraying at $30 \mathrm{DAS}$ & 26.56 & 27.88 & 27.22 & 44.90 & 48.72 & 46.81 & 49.72 & 51.90 & 50.81 & 11.30 & 13.12 & 12.21 \\
\hline $\mathrm{T}_{7}$ & CCC $500 \mathrm{mg} / \mathrm{L}$ spraying at $30 \mathrm{DAS}$ & 26.22 & 27.55 & 26.88 & 44.32 & 48.20 & 46.26 & 49.10 & 51.35 & 50.23 & 10.78 & 12.45 & 11.62 \\
\hline $\mathrm{T}_{8}$ & CCC $1000 \mathrm{mg} / \mathrm{L}$ spraying at $30 \mathrm{DAS}$ & 26.53 & 27.78 & 27.16 & 44.73 & 48.52 & 46.63 & 49.50 & 51.70 & 50.60 & 11.17 & 12.93 & 12.05 \\
\hline $\mathrm{T}_{9}$ & NAA $25 \mathrm{mg} / \mathrm{L}$ spraying at $30 \mathrm{DAS}$ & 26.40 & 27.78 & 27.09 & 43.78 & 47.78 & 45.78 & 48.62 & 50.82 & 49.72 & 10.42 & 12.13 & 11.28 \\
\hline $\mathrm{T}_{10}$ & NAA $50 \mathrm{mg} / \mathrm{L}$ spraying at $30 \mathrm{DAS}$ & 26.30 & 27.65 & 26.98 & 44.35 & 48.35 & 46.35 & 49.22 & 51.40 & 50.31 & 11.00 & 12.62 & 11.81 \\
\hline $\mathrm{T}_{11}$ & $\mathrm{CaCl}_{2} 2 \% \mathrm{SH}+1 \%$ spraying at $30 \mathrm{DAS}$ & 30.73 & 32.80 & 31.77 & 48.18 & 50.43 & 49.31 & 52.05 & 54.17 & 53.11 & 13.32 & 214.80 & 14.06 \\
\hline $\mathrm{T}_{12}$ & CCC $500 \mathrm{mg} / \mathrm{L} \mathrm{SH}+$ spraying at $30 \mathrm{DAS}$ & 29.55 & 31.32 & 30.43 & 47.45 & 49.83 & 48.64 & 51.40 & 53.47 & 52.43 & 12.68 & \begin{tabular}{|l|l|}
14.32 \\
\end{tabular} & 13.50 \\
\hline $\mathrm{T}_{13}$ & $\mathrm{CCC} 1000 \mathrm{mg} / \mathrm{L} \mathrm{SH}+$ spraying at $30 \mathrm{DAS}$ & 30.25 & 32.42 & 31.33 & 47.93 & 50.22 & 49.08 & 51.77 & 53.92 & 52.84 & 13.22 & 14.68 & 13.95 \\
\hline $\mathrm{T}_{14}$ & NAA $25 \mathrm{mg} / \mathrm{L} \mathrm{SH}+$ spraying at $30 \mathrm{DAS}$ & 29.12 & 30.62 & 29.87 & 46.67 & 49.45 & 48.06 & 50.92 & 52.88 & 51.90 & 12.20 & 14.00 & 13.10 \\
\hline $\mathrm{T}_{15}$ & NAA $50 \mathrm{mg} / \mathrm{L} \mathrm{SH}+$ spraying at $30 \mathrm{DAS}$ & 29.85 & 31.52 & 30.68 & 47.65 & 49.93 & 48.79 & 51.52 & 53.65 & 52.58 & 12.85 & 14.43 & 13.64 \\
\hline \multirow[t]{4}{*}{$\mathrm{T}_{16}$} & Absolute Control & 26.18 & 27.50 & 26.84 & 40.33 & 42.40 & 41.37 & 44.12 & 46.17 & 45.14 & 9.30 & 10.47 & 9.88 \\
\hline & S.Em. \pm & 1.26 & 1.42 & 0.85 & 1.51 & 1.51 & \begin{tabular}{|l|}
0.97 \\
\end{tabular} & 1.52 & 1.58 & 0.98 & 0.92 & 0.99 & 0.61 \\
\hline & C.D. @ 5\% & $\mathrm{NS}$ & NS & 2.40 & 4.35 & $\mathrm{NS}$ & 2.73 & 4.39 & NS & 2.77 & 2.65 & 2.86 & 1.71 \\
\hline & C.V. $\%$ & 7.62 & 8.12 & 7.90 & 5.82 & 5.46 & 5.64 & 5.37 & 5.35 & 5.36 & 14.27 & 713.55 & 13.90 \\
\hline
\end{tabular}

*SH- Seed Hardening

\section{Total Nitrogen $(\%)$}

The perusals of data presented in Table 2 revealed that the statistically non significant differences observed for the nitrogen content during both the years and significant results recorded on pooled basis. But it was observed that nitrogen content was improved due to the different treatments. The two years pooled data revealed that the nitrogen content recorded significantly maximum $(4.13 \%)$ in the treatment $\mathrm{T}_{11}$. While, the untreated absolute control treatment $\left(\mathrm{T}_{16}\right)$ recorded significantly the lowest $(3.65 \%)$ nitrogen content in pooled analysis. The results were in accordance with the findings of Kumar et al. (2018) ${ }^{[11]}$ and Damor \& Patel (2018) ${ }^{[5]}$ in mungbean.

Table 2: Effect of seed hardening, foliar spraying and their combined effect on Nitrogen and Seed Protein content at harvest

\begin{tabular}{|c|c|c|c|c|c|c|c|}
\hline \multirow{2}{*}{ Treat. No. } & \multirow{2}{*}{ Treatment Details } & \multicolumn{3}{|c|}{ Nitrogen content (\%) } & \multicolumn{3}{|c|}{ Seed protein content $(\%)$} \\
\hline & & 2016 & 2017 & Pooled & 2016 & 2017 & Pooled \\
\hline $\mathrm{T}_{1}$ & $\mathrm{CaCl}_{2} 2 \% \mathrm{SH}$ & 3.82 & 3.79 & 3.80 & 23.87 & 23.67 & 23.77 \\
\hline $\mathrm{T}_{2}$ & CCC $500 \mathrm{mg} / \mathrm{L} \mathrm{SH}$ & 3.77 & 3.74 & 3.75 & 23.53 & 23.37 & 23.45 \\
\hline $\mathrm{T}_{3}$ & $\mathrm{CCC} 1000 \mathrm{mg} / \mathrm{L} \mathrm{SH}$ & 3.80 & 3.77 & 3.78 & 23.72 & 23.57 & 23.64 \\
\hline $\mathrm{T}_{4}$ & NAA $25 \mathrm{mg} / \mathrm{L} \mathrm{SH}$ & 3.76 & 3.72 & 3.74 & 23.47 & 23.23 & 23.35 \\
\hline $\mathrm{T}_{5}$ & NAA $50 \mathrm{mg} / \mathrm{L} \mathrm{SH}$ & 3.78 & 3.75 & 3.76 & 23.63 & 23.42 & 23.53 \\
\hline $\mathrm{T}_{6}$ & $\mathrm{CaCl}_{2} 1 \%$ spraying at $30 \mathrm{DAS}$ & 3.96 & 3.90 & 3.93 & 24.77 & 24.35 & 24.56 \\
\hline $\mathrm{T}_{7}$ & CCC $500 \mathrm{mg} / \mathrm{L}$ spraying at $30 \mathrm{DAS}$ & 3.89 & 3.84 & 3.86 & 24.28 & 24.02 & 24.15 \\
\hline $\mathrm{T}_{8}$ & CCC $1000 \mathrm{mg} / \mathrm{L}$ spraying at $30 \mathrm{DAS}$ & 3.93 & 3.88 & 3.91 & 24.58 & 24.23 & 24.41 \\
\hline $\mathrm{T}_{9}$ & NAA $25 \mathrm{mg} / \mathrm{L}$ spraying at $30 \mathrm{DAS}$ & 3.85 & 3.81 & 3.83 & 24.08 & 23.82 & 23.95 \\
\hline $\mathrm{T}_{10}$ & NAA $50 \mathrm{mg} / \mathrm{L}$ spraying at $30 \mathrm{DAS}$ & 3.91 & 3.86 & 3.88 & 24.42 & 24.12 & 24.27 \\
\hline $\mathrm{T}_{11}$ & $\mathrm{CaCl}_{2} 2 \% \mathrm{SH}+1 \%$ spraying at $30 \mathrm{DAS}$ & 4.13 & 4.12 & 4.13 & 25.80 & 25.72 & 25.76 \\
\hline $\mathrm{T}_{12}$ & CCC $500 \mathrm{mg} / \mathrm{L} \mathrm{SH}+$ spraying at $30 \mathrm{DAS}$ & 4.02 & 3.99 & 4.01 & 25.15 & 24.95 & 25.05 \\
\hline $\mathrm{T}_{13}$ & CCC $1000 \mathrm{mg} / \mathrm{L} \mathrm{SH}+$ spraying at $30 \mathrm{DAS}$ & 4.08 & 4.03 & 4.06 & 25.48 & 25.20 & 25.34 \\
\hline $\mathrm{T}_{14}$ & NAA $25 \mathrm{mg} / \mathrm{L} \mathrm{SH}+$ spraying at $30 \mathrm{DAS}$ & 4.01 & 3.96 & 3.98 & 25.03 & 24.72 & 24.88 \\
\hline $\mathrm{T}_{15}$ & NAA $50 \mathrm{mg} / \mathrm{L} \mathrm{SH}+$ spraying at $30 \mathrm{DAS}$ & 4.04 & 4.00 & 4.02 & 25.27 & 25.00 & 25.13 \\
\hline \multirow[t]{4}{*}{$\mathrm{T}_{16}$} & Absolute Control & 3.69 & 3.61 & 3.65 & 23.08 & 22.55 & 22.82 \\
\hline & S.Em. \pm & 0.11 & 0.12 & 0.02 & 0.66 & 0.77 & 0.46 \\
\hline & C.D. @ 5\% & NS & NS & 0.06 & NS & NS & 1.28 \\
\hline & C.V. \% & 4.69 & 5.55 & 5.13 & 4.69 & 5.55 & 5.13 \\
\hline
\end{tabular}

*SH- Seed Hardening

\section{Seed Protein content (\%)}

The data presented in Table 2 indicated that even though, the statistically non significant differences observed for the seed protein content during both the years but protein content was improved due to the different treatments. The two years pooled data revealed that the seed protein content recorded significantly maximum $(25.76 \%)$ in the treatment $\mathrm{T}_{11}$ and it remained at par with the treatments $\mathrm{T}_{13}(25.34 \%), \mathrm{T}_{15}$ (25.13\%), $\mathrm{T}_{12}(25.05 \%), \mathrm{T}_{14}(24.88 \%)$ and $\mathrm{T}_{6}(24.56 \%)$ in pooled. While, the untreated absolute control treatment $\left(\mathrm{T}_{16}\right)$ recorded significantly the lowest $(22.82 \%)$ seed protein content.

From the above results, it is clear that there was increase in seed protein content in all the treatments like seed hardening, foliar spraying singly or their combined effect as compared to control. Similarly, the higher seed protein content was reported by Sujatha (2014) ${ }^{[19]}$ in chickpea. Avijit and Misra, $(1987)^{[2]}$ in wheat, Doijode $(1975)^{[7]}$ in garden peas. Bora and Sarma (2005) ${ }^{[4]}$ in pea. Shukla et al. (2018) ${ }^{[18]}$ in chickpea 
and Kumar et al. (2015) ${ }^{[12]}$ in field bean and Damor \& Patel (2018) ${ }^{[5]}$ in mung bean.

\section{Conclusion}

On the basis of above findings it can be concluded that pre sowing seed hardening with $2 \% \mathrm{CaCl}_{2}+1 \%$ spraying at 30 DAS and other treatments also played an effective role in improving biochemical characters in green gram. Improvement of seed quality by seed hardening with $2 \%$ $\mathrm{CaCl}_{2}+1 \%$ spraying at 30 DAS is a simple and easy approach to enhance the chlorophyll content of leaves, nitrogen content, seed protein content, overall seed performance and thereby agricultural productivity especially in the dry land and marginal lands of resource poor farmers.

\section{References}

1. AOAC. Association of Official Analytical Chemist, official method of analysis, $15^{\text {th }}$ (Edn). Washington DC, 1990.

2. Avijit S, Misra NM. Effect of pre-sowing seed treatments and phosphate doses on yield, quality and nutrient uptake of wheat. Agricultural Science Digest. 1987; 7:213-16.

3. Bewley JD, Black M. Physiology and biochemistry of seeds in relation to germination, Springer, Berlin. 1982; $2: 375$.

4. Bora RK, Sarma CM. Effect of growth regulators on growth and yield of pea. Advance Plant Science. 2005; 18(11):835-39.

5. Damor PR, Patel AD. Effect of source manipulation, plant growth regulators and chemical on biochemical parameters in green gram (Vigna radiata L. Wilckzek) cv. GAM-5. International Journal of Chemical Studies. 2018; 6(4):2089-2091.

6. Dashora LD, Jain PM. Effect of growth regulators and phosphorus levels on growth and yield of soybean. Madras Agricultural Journal. 1994; 81:235-37.

7. Doijode SD. Effect of growth regulators on growth and yield of garden pea (Pisum sativum var. hortense L.) M.Sc. (Agri.) Thesis, University of Agricultural Sciences, Bangalore, Karnataka, India, 1975.

8. Jayakumar P, Thangaraj M. Physiological and biochemical effects of mepiquat chloride in groundnut (Arachis hypogaea). Madras Agricultral Journal. 1998; 85:23-26.

9. JunMin H, Xiaoping S, Jian Z. Mitigative effects of hydration-dehydration treatments on salt stress induced injury to tomato seed germination. Deta. Hort. Sinica. 2000; 27:123-126.

10. Kinjal $\mathrm{R}$ Prajapati. Effect of seed hardening on germination, growth and yield of black gram (Vigna mungo L.). M. Sc. (Agri.) Thesis, Anand Agricultural University, Anand, Gujarat, India, 2017.

11. Kumar R, Yadav RK, Sharma N, Yadav A, Nehal N. Influence of plant growth regulators on biochemical changes of mungbean (Vigna radiata L. Wilczek). Journal of Pharmacognosy and Phytochemistry. 2018; 1:386-389.

12. Kumar SE, Channaveerswami AS, Naik VR, Krishna A. Effect of nipping and hormonal spray on seed yield and quality of field bean genotypes. 8th National Seed Congress, Hyderabad, 2015, 223-224.

13. Miller L, Houghton JA. The micro-kjeldahl determination of the nitrogen content of amino acids and proteins. Biological Chemistry. 1945; 159:373-383.
14. Patel DB, Bhadane RS, Dhruva JJ, Shukla YM. Effect of seed hardening chemicals on morpho-physiological attributes in green gram (Vigna radiata L.). International Journal of Chemical Studies. 2017; 5(6):05-07.

15. Pothalkar SM. Physiological investigations on drought tolerance in pigeonpea (Cajanus cajan L.). Ph. D. Thesis, University of Agricultural Sciences, Dharwad, Karnataka, India, 2007.

16. Sankar Ganesh K, Sundaramoorthy P, Baskaran L, Rajesh M, Rajasekaran S. Effect of Pre-sowing Hardening Treatments Using Various Plant Growth Hormones on Two Varieties of Green Gram Germination and Seedling Establishment. International Journal of Modern Biology and Medicine. 2013; 3(2):78-87.

17. Shinde AK, Jadhav BB. Influence of NAA, ethrel and $\mathrm{KNO}_{3}$ on leaf physiology and yield of cowpea. Annals of Plant Physiology. 1995; 9:43-46.

18. Shukla AK, Singh RK, Pandey AK, Gautam MK, Vishen GS. Effect of growth regulators and nipping on biochemical traits and yield attributes of chickpea (Cicer arietinum L.). International Journal of Chemical Studies. 2018; 6(1):438-442.

19. Sujatha M. Studies on effect of seed hardening, nipping and foliar spray of cycocel on growth, yield and quality of chickpea (Cicer arietinum L.). M. Sc. (Agri.) Thesis, University of Agricultural Sciences, Dharwad, Karnataka, India, 2014.

20. Taiz L, Zeiger E. Auxin - the growth hormone. Plant Physiology, Panima Publishing Croporation, New Delhi, 2003, 423-456. 